\title{
АНТОЦІАНИ Й АНТОЦІАНІДИНИ ЯК КОМПОНЕНТИ ФУНКЦІОНАЛЬНОГО ХАРЧУВАННЯ: БІОХІМІЯ ТА ВПЛИВ НА ЗДОРОВ'Я ЛЮДИНИ (ОГЛЯД ЛІТЕРАТУРИ)
}

\begin{abstract}
Вступ. Антоціани й антоціанідини - це два типи червоно-синіх рослинних фрлавоноїдів, які в основному містяться у квітках і плодах вищих рослин. Головна відмінність між антоціаном та антоціанідином полягає в тому, що антоціан є водорозчинним вакуолярним пігментом, тоді як антоціанідин - аналогом антоціану без цукру. Антоціани утворюються в результаті додавання цукрів до різних бічних груп іона фрлавілію. Пігменти перебувають у глікозильованих фрормах. Ціанідин, дельфінідин, мальвідин, пеонідин, петунідин і пеларгонідин - це шість поширених антоціанідинів. Крім використання антоціанідинів та антоціанів як природних барвників, ці кольорові пігменти є потенційними фрармацевтичними інгредієнтами, які мають різні корисні ефекти для здоров'я. Наукові дослідження, такі, як дослідження на культурі клітин, моделі на тваринах іклінічні випробування на людях, показують, що антоціанідини й антоціани мають антиоксидантну та антимікробну активність, покращують зорове і неврологічне здоров'я та захищають від різних захворювань.

У цьому огляді узагальнено найновішу літературу щодо біологічних переваг дієтичних антоціанів, включаючи протипухлинну активність, протизапальну активність, нейропротекторну активність, запобігання серцево-судинним захворюванням, ожиріння та антидіабетичну активність, особливу увагу зосереджено на молекулярних механізмах дії. Даний огляд допоможе краще зрозуміти, що являють собою ці дієтичні фрітохімічні речовини та як їх застосовувати на користь для здоров'я людини. У роботі використано загальнонаукові методи дослідження, що включають експертно-аналітичний огляд наукових джерел, аналіз і синтез літературних даних.

Мета дослідження - узагальнити основні знання про біохімію, регулювання біосинтезу антоціанів у рослинах, молекулярних механізмів дії, висвітлити деякі аспекти, що стосуються антиоксидантної активності антоціанів та їх біодоступності, й обговорити останні експериментальні дані, пов'язані зі сприятливим впливом на здоров'я людини.

Висновок. Аналіз літературних джерел обірунтовує актуальність дослідження молекулярних механізмів дії антоціанів, важливість цих сполук як природних барвників, маркерів стресу для рослин і профрілактики багатьох хронічних захворювань у людини та використання їх для запобігання ряду захворювань.

КЛЮЧОВІ СЛОВА: антоціани; антоціанідини; пігменти; антиоксиданти; ефект протизапальний, протипухлинний, протидіабетичний; офтальмологія.
\end{abstract}

Широка доступність гіперкалорійних продуктів і збільшення споживання оброблених харчових продуктів, особливо в західних країнах, призводять до епідемії хронічних неінорекційних захворювань: серцево-судинних, метаболічних та нейродегенеративних. 3 огляду на це, в останні роки зріс інтерес до рослин та їжі, що мають антиоксидантні властивості. 3 такої точки зору, заохочується споживання свіжих продуктів, що містять біологічно активні сполуки, які забезпечують захист здоров'я на багатьох різних рівнях. Дійсно, свіжі продукти, зокрема рослинна їжа, містять безліч біологічно активних сполук, таких, як полісренольні сполуки, які здатні модулювати (с) І. П. Кузьмак, 2021. різні шляхи і процеси в нашому організмі й проявляти антиоксидантну, протизапальну, протипухлинну, глюкозорегулювальну і нейропротекторну активність [1]. Як компоненти фрункціонального живлення активно досліджують різні біологічно активні сполуки, серед яких антоціани привертають особливу увагу. Ці сполуки є водорозчинними пігментами, забарвлення яких, залежно від структури і $\mathrm{pH}$ середовища, може варіювати від червоного та пурпурного до синього кольору.

Хімічними сполуками 3 антиоксидантними властивостями, що містяться в овочах і фрруктах, $€$ вітаміни C та E, каротиноїди і фрлавоноїди. Власне антоціани і належать до цієї великої 
групи сполук, відомих як фрлавоноїди, що є підгрупою ще більшої групи сполук - поліфенолів. Дані пігменти є найважливішою групою фрлавоноїдів у рослинах з катіоном фрлавілієвої структури (AH+), які діють як кислота. Власне ця структура безпосередньо пов'язана з його антиоксидантною активністю. Більшість фрункціональних властивостей антоціанів можна пояснити їх хімічною реакційною здатністю.

Антоціани $є$ водорозчинними вакуолярними пігментами, які наявні переважно у плодах і квітках, а також у вегетативних органах. Вони мають сильний вплив на сенсорні властивості їжі, оскільки забезпечують характерний червоно-синій колір фрруктів та овочів. Антоціани відіграють ключову роль у запиленні рослин і, поглинаючи світло, захищають їх від ушкоджень, викликаних УФ-променями, та холодового стресу [1-8].

Основною функцією антоціанів, що містяться у квітках або епідермісі плодів, є залучення тварин і комах-запилювачів, щоб легко розповсюдити насіння чи полегшити поширення пилку. Однак докази того, що синтез антоціанів індукується під час встановлення несприятливих умов, свідчать про їх участь як у біотичних, так і абіотичних стресах.

Пігменти перебувають у глікозильованих формах. Антоціани, які відповідають за червоний, фріолетовий та синій кольори, містяться у фруктах і овочах.

Основними джерелами антоціанів є темнозабарвлені плоди, серед яких ягоди бузини, горобини чорноплідної, граната і чорниці - лідери за вмістом цих сполук. Ягоди, смородина, виноград та деякі тропічні фррукти теж мають високий вміст антоціанів. Останнім часом як джерела антоціанів стали розглядати більш екзотичні в цьому відношенні культури, такі, як злаки і картопля, зерно та бульби від червоного до фріолетово-синього кольору, що також здатні накопичувати антоціанові сполуки [9]. Антоціани наявні в усіх тканинах вищих рослин, включаючи листки, стебла, коріння, квітки та плоди. Серед антоціанових пігментів ціанідин-3-глюкозид $€$ основним антоціаном, який міститься в більшості рослин. Кольорові антоціанові пігменти традиційно використовують як натуральні харчові барвники. На колір і стабільність цих пігментів впливають рН, світло, температура та структура. У кислому стані антоціани виглядають як червоні, але стають синіми при підвищенні pH [7].

Структура, біодоступність та різноманітність антоціанів

Антоціанідини є похідними катіона фрлавілію, в якого кисень у пірановому кільці має вільну валентність. Антоціани - ширший термін, що включає як антоціанідини, так і їх глікозиди. Сама назва "антоціани" походить від грецьких слів anthos - квітка і kyanos - синій.

Молекула антоціану складається з "ядра" антоціанідину з приєднаною цукровою частиною (схема 1). Антоціанідини рідко трапляються в природі у вигляді вільних агліконів через їх нестабільність, тому, коли вони глікозильовані однією або кількома молекулами цукру, їх називають антоціанами.

Антоціани відрізняються за кількістю і положенням гідроксильних та метоксильних груп, приєднаних до антоціанідину. Таким чином, хоч існує майже 25 антоціанідинів, які трапляються в природі, на сьогодні виявлено понад 700 похідних антоціанів [10].

Отже, в структурі антоціанів виділяють вуглеводний залишок і невуглеводну основу - аглікон. Усі фрлавоноїди, включаючи антоціани, мають загальний 15-карбоновий скелет $\mathrm{C}_{6}-\mathrm{C}_{3}-\mathrm{C}_{6}$, який складається 3 двох ароматичних кілець А та В, з'єднаних $\mathrm{C}_{3}$-сррагментом (див. схему 1). Ступінь окиснення С-кільця визначає клас флавоноїдів, до якого належить сполука. У антоціанів С-кільце має два подвійні зв'язки та несе позитивний заряд (іон фрлавілію).

При загальній будові $\mathrm{C}_{15}$-карбонового скелета в класі антоціанів індивідуальні сполуки виділяють на основі наявності, положення та характеру модифікацій основного скелета. Усі антоціанові сполуки $є$ глікозидами, отриманими в результаті приєднання цукрів до агліконів, серед яких найбільш поширені глюкоза (Glu) і рамноза (Rha), а також зустрічаються галактоза (Gal), арабіноза (Ara), ксилоза (Xyl), рутиноза (Rut), можуть траплятися дисахариди, дуже рідко - трисахариди. Крім глікозилювання, антоціани можуть піддаватися ацилюванню за допомогою ароматичних або аліфатичних ацильних залишків,<smiles></smiles>

\begin{tabular}{||c|c|c||}
\hline $\mathrm{R}_{1}$ & $\mathrm{R}_{2}$ & Антоціанідин \\
\hline $\mathrm{H}$ & $\mathrm{H}$ & Пеларгонідин \\
\hline $\mathrm{OH}$ & $\mathrm{H}$ & Ціанідин \\
\hline $\mathrm{OCH}_{3}$ & $\mathrm{H}$ & Пеонідин \\
\hline $\mathrm{OH}$ & $\mathrm{OH}$ & Дельсрінідин \\
\hline $\mathrm{OCH}_{3}$ & $\mathrm{OH}$ & Петунідин \\
\hline $\mathrm{OCH}_{3}$ & $\mathrm{OCH}_{3}$ & Мальвідин \\
\hline
\end{tabular}

Схема 1. Загальна структура антоціанідинів. 
найбільш поширеними з яких є п-кумарова, кавова та фрерулова кислоти. Антоціанові сполуки також можуть піддаватися метилюванню та метоксилюванню $[9,10]$.

Таким чином, антоціани відрізняються за: а) положенням і кількістю гідроксильних груп; б) ступенем метилювання гідроксильних груп; в) природою та кількістю молекул цукру, приєднаних до аглікону; г) приєднаними до молекули цукру аліфратичними або ароматичними кислотами.

У природі найбільш поширені такі антоціанідини, як пеларгонідин (Pg), ціанідин (Су), пеонідин (Pn), дельфінідин (Dp), петунідин (Pt) i мальвідин (Mv), причому 90 \% ідентифрікованих антоціанів $€$ саме їх похідними. Їх молекулярні структури показано на схемі 2.

Більшість антоціанів у харчових продуктах $€$ похідними ціанідину, за ними йдуть дельфрінідин та пеларгонідин і три метильовані антоціани (пеонідин, мальвідин, петунідин). Розподіл цих антоціанідинів у фрруктах і овочах становить, відповідно, 50 \%, 12 \%, 12 \%, 12 \%, 7 \% та 7 \%.

Глікозиди трьох неметильованих антоціанідинів (ціанідин, дельфрінідин і пеларгонідин) найбільш поширені в природі, вони наявні у $80 \%$ пігментованих листків, 69 \% плодів та 50 \% квіток. В їстівних частинах рослин найбільш поширений такий антоціан, як ціанідин (тобто його глікозид ціанідин-3-глюкозид), отже, він є найбільш вивченою сполукою [2, 5-7, 10-12].

Ціанідин (Су) зазвичай пурпурного та малинового кольорів. Основними його джерелами $є$ яблука, ожина, чорна малина, бузина, шовковиця, чорниця, агрус, персик, груша, апельсин, слива, виноград, вишня, полуниця, інжир, червона цибуля, червонокачанна капуста, червона солодка картопля, картопля, фріолетова морква. Це основний пігмент у ягодах та інших овочах червоного кольору, таких, як червона солодка картопля і сріолетова кукурудза.

Пеларгонідин (Pg) відрізняється від більшості антоціанідинів. У природі він зустрічається у вигляді пігменту червоного кольору. Пеларгонідин надає помаранчевого відтінку квітам і червоного - деяким фрруктам і ягодам. Він має унікальний помаранчевий лососевий колір. Його можна виявити в різних овочах і фрруках, таких, як полуниця, чорниця, банан, червона редька та картопля [7, 10, 13].

Пеонідин (Pn) має пурпурний колір. Його можна виявити в манго, винограді, сливах, картоплі, бататі, червоних винах.

Дельфінідин (Dp) зазвичай буває різних кольорів: фріолетового, лілового і блакитного. Синього відтінку квітам надає саме цей пігмент [5]. Основними його джерелами є маракуя, баклажани, зелена квасоля, гранат, чорниця, виноград.

Мальвідин (Mv) має фріолетовий колір, і на нього багаті блакитно-фріолетові квіти. Він насамперед відповідає за колір чорниці та червоного винограду. Мальвідин також $є$ основним червоним пігментом червонного вина [7, 10, 13].

Петунідин (Pt) має фріолетовий колір і міститься в чорниці та винограді.

Колір антоціанів: на інтенсивність і тип забарвлення антоціанів впливає кількість гідроксильних та метоксильних груп в їх структурі. Якщо вони містять більше гідроксильних груп (ОН),

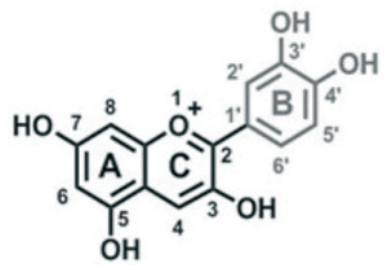

Ціанідин<smiles>Oc1cc(O)c2cc(O)c(-c3cc(O)c(O)c(O)c3)[o+]c2c1</smiles>

Дельфінідин<smiles>Oc1ccc(-c2[o+]c3cc(O)cc(O)c3cc2O)cc1</smiles>

Пеларгонідин<smiles>COc1cc(-c2[o+]c3cc(O)cc(O)c3cc2O)ccc1O</smiles>

Пеонідин<smiles>COc1cc(-c2[o+]c3cc(O)cc(O)c3cc2O)cc(OC)c1O</smiles>

Мальвідин<smiles>COc1cc(-c2[o+]c3cc(O)cc(O)c3cc2O)cc(O)c1O</smiles>

Петунідин

Схема 2. Хімічна структура основних антоціанідинів: ціанідину, пеларгонідину, пеонідину, дельфінідину, мальвідину і петунідину. 
колір переходить до більш блакитного відтінку. 3 іншого боку, почервоніння посилюється, якщо переважають метоксильні групи [10].

Зі збільшенням кількості фенольних гідроксильних груп колір плодів змінюється від рожевого, через помаранчево-червоний, до синього, як це спостерігають у ряді ціанідин $\rightarrow$ мальвідин $\rightarrow$ дельфінідин. Метилювання гідроксильної групи змінює колір у цьому ряді у зворотному напрямку. Крім числа гідроксильних груп, на колір впливає і положення даних груп у молекулі [5, 10].

Антоціанові пігменти широко використовують як натуральні харчові барвники. Однак на колір і стабільність цих пігментів впливають рН, світло, температура та структура. При кислому рН антоціани є червоними пігментами, а в основному середовищі вони стають синіми. Однак при основному рН антоціани не стабільні й мають тенденцію розкладатися до темно-коричневих окиснених сполук [1, 5]. Стабільність антоціанів також залежить від В-кільця в їх структурі та наявності гідроксильних або метоксильних груп. Справді, наявність іона оксонію, що знаходиться поруч із карбоном, який перебуває в положенні 2, робить антоціани особливо чутливими до нуклеофрільної атаки з боку таких сполук, як діоксид сірки, аскорбінова кислота, пероксид водню або вода. На їх стабільність також можуть впливати наявність іонів металів, температура, світло та кисень [5].

Антоціани дуже стабільні й сильно забарвлені при низькому рН (pH 1-3). У разі зростання рН ці молекули змінюють свою хімічну структуру, а також колір. При рН 1-3 катіон фрлавілію переважає і домінують фріолетовий та червоний кольори. pH 4-5 створює безбарвний карбінол. При рН 6-7 домінують хіноїдні синьо-оріолетові види, при рН 7-8 - халконові, також практично безбарвні. У водній фразі перебувають ці чотири хімічні фрорми рівноваги один з одним; поширена форма залежить від рН розчину. Точніше біодоступність антоціанів низька через їх чутливість до зміни $\mathrm{pH}[8,14]$.

Антоціани, як правило, стабільні при значеннях рН 3,5 або нижчих, тому стабільні при кислій кислотності шлунка (рH 2). Однак ці молекули швидко розкладаються при вищих значеннях рH (pH 7), наприклад у кишечнику, тому корисна біодоступність може бути значно зменшена. Різні ефекти спостерігають після тривалого споживання багатих на антоціани продуктів або їх екстрактів, що демонструють високу міжіндивідуальну біодоступність і біоактивність [15].

Біосинтез антоціанів та його регуляція

Біосинтез антоціанів регулюється не тільки генетично, але й фрізіологічно. Ці метаболіти синтезуються френілпропаноїдним шляхом, і френілаланін є вихідною сполукою. Шлях має розгалужений характер та продукує проміжні продукти, що діють як попередники для утворення величезної різноманітності сполук, у тому числі антоціанів і транс-ресвератролу.

Шлях біосинтезу антоціанів становить важливу гілку шляху фенілпропаноїдів і на початкових стадіях поділяє деякі біосинтетичні ензими для інших фрлавоноїдів, таких, як фрлавони та фллавонони. Починається 3 фенілаланіну, який перетворюється в коричну кислоту за допомогою френілаланін-аміак-ліази (PAL) (схема 3).

Фенілаланін-аміак-ліаза (PAL) - ключовий ензим, оскільки він $є$ першою контрольною точкою маршруту. Корична кислота потім перетворюється в кумаринову кислоту під дією циннамат-4-гідроксилази (С4H), далі - в 4-кумароїл-КоА під дією ензиму 4-кумароїл-КоА-лігази (4CL). Після конденсації 4-кумароїл-КоА з малоніл-КоА утворюється нарингенін халкон (ензим халконсинтаза (CHS)), а потім перетворюється в нарингенін під дією ензиму халконізомерази (CHI). Наступний етап - це утворення дигідрофлавонолів, таких, як дигідрокемпферол і дигідрокверцетин, з участю ензимів фрлавонон-3-гідроксилази (F3H) та фрлавоноїд 3'-гідроксилази (F3'H) відповідно. Останні кроки біосинтетичного шляху призводять до вироблення лейкоціанідинів, ціанідинів та антоціанів дигідросрлавонолредуктазою (DFR), антоціанідинсинтазою (ANS) й UDP-глюкоза:срлавоноїд-3-О-глікозилтрансореразою (UFGT) відповідно [1]. Це останній ензим у маршруті, що додає молекулу глюкози до утворених антоціанідинів, забарвлюючи їх і синтезуючи власне антоціани.

Після утворення антоціанів вони можуть бути ацильовані в їх глюкозний залишок, включаючи ацетилову або кумароїльну групу. В той час як біосинтез антоціанів відбувається в цитозолі, вони зберігаються у вакуолі, куди потрапляють за допомогою специфічних мембранних транспортерів [16].

Деякі аспекти біодоступності антоціанів

Всмоктування, метаболізм і виведення антоціанів залежать від харчової матриці, включаючи інші антиоксиданти та макроелементи, наявні у звичайній дієті, що, отже, впливає на біодоступність антоціанів [15].

Фармакокінетика антоціанів і метаболіти 3 кількох продуктів свідчать про те, що шлунковокишковий тракт є їх основною мішенню. J. Fang [17] підсумував, як деякі антоціани можуть ефрективно поглинатися з просвіту шлунково-кишкового тракту, піддаються інтенсивному метаболізму першого проходження та потрапляють у системний кровообіг як метаболіти, які погано 
всмоктуються і швидко виводяться з плазми, проте це не нівелює їх позитивного впливу для профрілактики багатьох захворювань [15]. Останні наукові розробки підкреслюють потенційний синергетичний ефрект між вихідними сполуками, метаболітами (фрази I та II), кон'югованими продуктами і метаболітами, створеними мікробами, щоб пояснити ці біологічні процеси [8].
Під час процесу травлення антоціани зазнають інтенсивної зміни рН, що разом із фрерментативною та бактеріальною дією може спричинити гідроліз і перетворення антоціанів у метаболіти, кон'юговані продукти або простіші френольні сполуки. Таким чином, антоціани перетворюються в більш біодоступні та легше засвоювані фрорми [18].

френілаланін

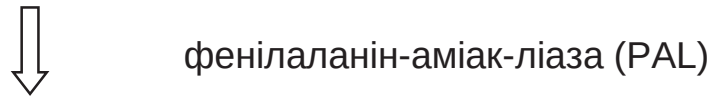

корична кислота

$\sqrt{7}$ циннамат-4-гідроксилаза $(\mathrm{C} 4 \mathrm{H})$

кумаринова кислота

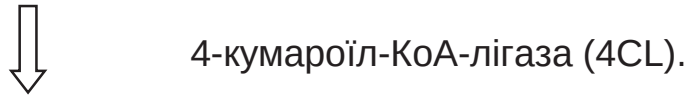

4-кумароїл-КоА + малоніл-КоА

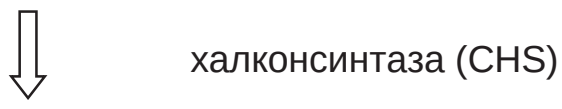

нарингенін халкон

Ц

и

$\mathrm{T}$

$\mathrm{O}$

$\Pi$

л

A

3

M

A халконізомераза (CHI)

нарингенін

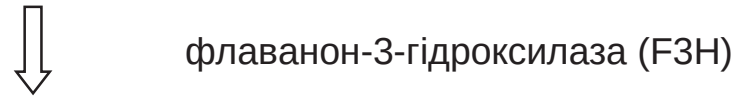

дигідрокемпферол

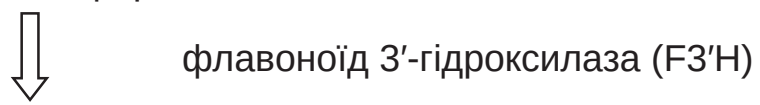

дигідрокверцетин

дигідрофлавонолредуктаза (DFR)

лейкоціанідин

$\sqrt{ }$ антоціанідинсинтаза (ANS)

ціанідин

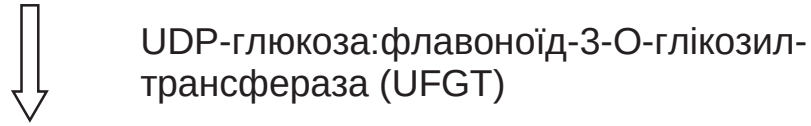

антоціан

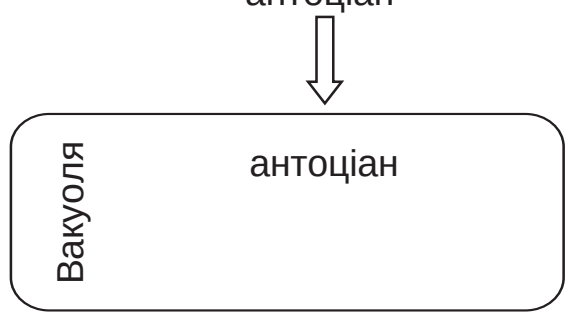

Схема 3. Шлях біосинтезу антоціанів. 
Крім того, F. Cardona та ін. [19] стверджують, що на ці молекули в організмі впливає ферментативна діяльність мікробної спільноти кишечника. Після вивільнення їх метаболіти сприяють підтримці здоров'я кишечника шляхом модуляції його мікробного балансу за рахунок стимуляції росту корисних бактерій та пригнічення патогенних бактерій, що сприяє пребіотичному ефекту. Міжіндивідуальні відмінності в складі мікробіоти можуть спричинити відмінності в біодоступності й біоефективності антоціанів та їх метаболітів.

Дуже цікаво відзначити, що ці продукти, у свою чергу, можуть модулювати склад мікробіоти товстої кишки. Справді, багато авторів помітило, що вживання антоціанів викликає збільшення кількості корисних бактерій, таких, як біфідобактерії, лактобактерії або актинобактерії [20-22].

Більше того, A. Smeriglio та ін. [23] підкреслили вплив поліморфрізму ензимів людини, які беруть участь у механізмах біотранссрормації, на біодоступність антоціанів.

Вплив антоціанів на органи-мішені, механізм дії на деякі метаболічні шляхи, кінцеві наслідки

Протягом останніх кілька років було проведено багато досліджень для виявлення зв'язку між антоціановими сполуками і гіперліпідемією, гіперглікемією, артеріальною гіпертензією, запаленням та впливом на імунітет, що, у свою чергу, викликають цукровий діабет, серцевосудинні захворювання й інші захворювання, пов'язані із запаленням [1, 5-11, 15, 23-39].

На схемі 4 підсумовано вплив антоціанів на органи-мішені й механізм дії кількома шляхами та їх кінцеві наслідки для здоров'я і самопочуття [15].

Антоціани відомі як сполуки, що можуть модулювати механізми гомеостазу глюкози, ліпідів та амінокислот і пригнічують запалення. Більшу увагу звернено на розробку альтернативних стратегій і можливих методів лікування, спрямованих на дисреренціацію адипогенезу, транспортування та надходження глюкози, послаблення запалення, і зміни імунної відповіді [15].

Таким чином, антоціани діють на скелетні м'язи, печінку, підшлункову залозу і жирову тканину (див. схему 4) для стимуляції різних запальних цитокінів, метаболічних ензимів та сигнальних шляхів, проявляючи протизапальну, антиоксидантну і метаболічно-стабілізувальну активність. Ці механізми пов'язані зі стабілізацією

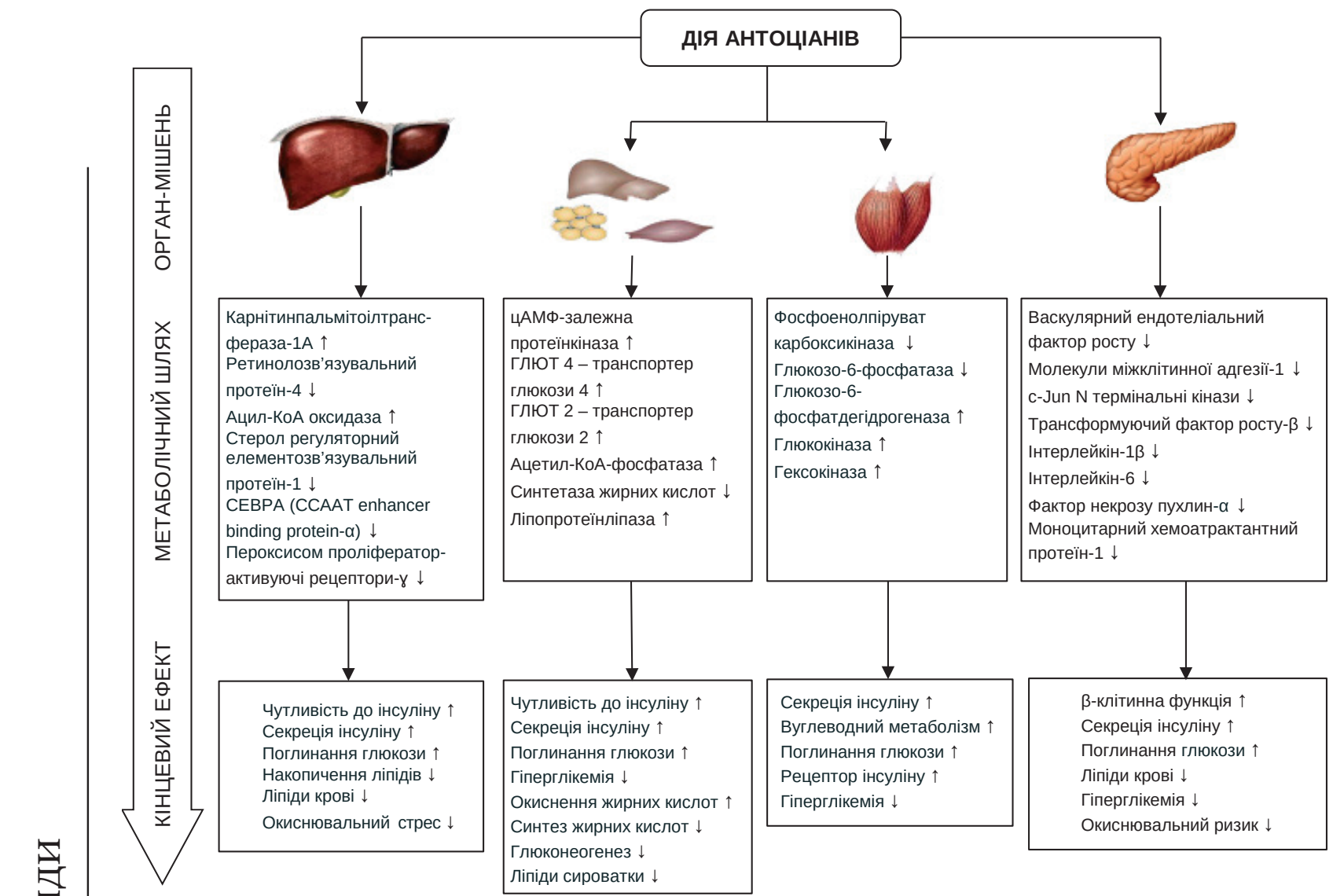

Схема 4. Вплив антоціанів на органи-мішені й механізм їх дії через деякі метаболічні шляхи та їх кінцевий вплив на здоров'я людини. 
ожиріння і цукрового діабету, покращенням артеріального тиску та ліпідних профрілів, зменшенням розвитку атеросклерозу і поліпшенням судинної фрункції [15]. Механізми дії антоціанідинів та антоціанів при просрілактиці захворювань обговорено нижче.

\section{Антоціани як антиоксиданти}

Живі клітини виробляють побічні продукти під час метаболізму у вигляді активних фрорм кисню (АФК) та вільних радикалів за нормальних і стресових умов. Активні форми кисню - це група реакційноздатних молекул, отриманих 3 молекулярного кисню, таких, як супероксид $\left(\mathrm{O}_{2}{ }^{-}\right)$, синглетний кисень $\left({ }^{1} \mathrm{O}_{2}\right)$, пероксид водню $\left(\mathrm{H}_{2} \mathrm{O}_{2}\right)$ і гідроксильний радикал $\left(\mathrm{OH}^{-}\right)$. Вони можуть викликати ушкодження клітин при надмірному виробленні.

Антоціани й антоціанідини мають більшу антиоксидантну властивість порівняно з іншими орлавоноїдами завдяки особливій хімічній структурі. Антиоксидантну здатність цих сполук можна пояснити тим, що хелатні іони металів беруть участь в утворенні вільних радикалів, тим самим зменшуючи спричинене металами пероксидне окиснення [10].

Оздоровчий і терапевтичний ефект антоціанів пов'язаний з їх хімічною та біохімічною реактивністю, що частково можна пояснити їх антиоксидантною активністю. Однак антиоксидантна активність антоціанів не обов'язково переходить на біологічну активність, оскільки будь-яка дія на організм залежить як від біодоступності, так і від клітинних молекулярних мішеней. Крім того, не всі сині, червоні й фріолетові фрукти, овочі та квіти мають однакові склад і концентрацію антоціанів та, як наслідок, однакову антиоксидантну активність. Найбільше антоціанів містять ягоди, смородина, виноград, деякі тропічні фррукти [24]

Таким чином, антоціани й антоціанідини, як і інші поліфеноли та фрлавоноїди, мають здатність діяти як поглиначі вільних радикалів проти шкідливих окиснювачів, таких, як активні фрорми кисню та азоту. Флавілієвий скелет надає антоціанам особливих властивостей, пов'язаних 3 радикальною електронною делокалізацією на $\mathrm{sp}^{2}$-орбіталях оксонієвої частини. Центральна роль антиоксидантної активності - окиснення фенольних гідроксильних груп антоціанів, зокрема, пара- та ортофенольні групи є важливими для утворення семіхінонів та для стабілізації продуктів одноелектронного окиснення [1, 25, 26].

Структура і властивості антоціанів залежать від різних фракторів, таких, як рН, температура та розчинники, які слід контролювати для проведення досліджень антиоксидантної активності цих сполук $[1,7,8,25,26]$.
Вільні радикали, активні фрорми кисню та/або реактивні форми азоту необхідні для належної діяльності людського організму і його органів. Ці радикали врівноважуються окиснювально-відновним гомеостазом у нашому організмі. Однак організм іноді може постраждати від окиснювального стресу, що виникає в результаті порушення рівноваги. Цей стрес важливий у розвитку хронічних дегенеративних захворювань, включаючи ішемічну хворобу серця, рак і старіння [27]. Антоціани описано як сполуки, що запобігають або пригнічують окиснення шляхом знешкодження вільних радикалів і зменшення окиснювального стресу. На регулярній основі антоціани діють як донор Н-атома або як одиночний переносник електрона [8].

Захист цих пігментів від процесів окиснення залежить від їх структури. Не всі вони виконують однакові фрункції для поглинання різноманітних активних форм кисню або азоту. Антиоксидантна здатність антоціанів залежить від орієнтації кільця, оскільки вона визначатиме готовність віддати протон і здатність передавати й електрон. Кількість вільних гідроксилів навколо піронового кільця та їх положення також відіграють ключову роль в антиоксидантній активності [27].

Важливе значення для антиоксидантної активності має також наявність інших типів радикалів у головній структурі. Отже, халкони антоціанів і хіноїдні основи з подвійним зв'язком, сполученим з кетогрупою, є ефективними антиоксидантами при очищенні вільних радикалів. Крім того, глікозильована В-кільцева структура антоціанів сприяє збільшенню антиоксидантної активності, ортогідроксилювання та метоксилування істотно підвищують їі. До того ж, антоціанідини мають більшу антиоксидантну активність, ніж антоціани, про що повідомлялося в літературі. Причиною може бути нижча стабільність антоціанідину порівняно з антоціаном через його структуру, що, отже, робить антоціанідин високореактивним. Ацилювання антоціанів однією або кількома фенольними кислотами впливає на підвищення антиоксидантної активності, але глікозилювання призводить до її зниження [7]. Таким чином, антиоксидантна активність цих сполук залежить від їх загальної концентрації, структури та середовища.

Раніше передбачалося, що тільки антиоксидантні властивості антоціанів відповідальні за їх ефекти, що зміцнюють здоров'я. Однак було показано, що вони здатні взаємодіяти з регуляторними протеїнами, а також компонентами сигнальних шляхів і, таким чином, модулювати фрізіологічні процеси, що перебігають в організмі людини [9]. 
Антоціани можуть знешкоджувати вільні радикали двома гіпотетичними шляхами. Перший шлях - це атака ОН-групи (груп) В-кільця, а другий - атака іона оксонію на С-кільце. Деякі 3 них вважають одними 3 найсильніших антиоксидантів завдяки застосуванню обох шляхів [7].

Більшість широко розповсюджених антоціанідинів та антоціанів проявляє вищу поглинальну активність, ніж добре відомі сильні антиоксиданти, наприклад, ціанідин має антиоксидантну здатність, більшу до 4,4 раза, ніж аскорбінова кислота й аналог вітаміну E [10].

Серед антоціанових агліконів найвищою антиоксидантною активністю володіють дельфрінідин і ціанідин, далі в порядку зменшення мальвідин, пеонідин, пеларгонідин, петунідин [9].

\section{Антоціани для здоров'я очей}

Сприятливий вплив антоціанів на покращення зору було вперше задокументовано під час Другої світової війни, коли льотчики Королівських військово-повітряних сил Британії для підвищення гостроти зору в темний час доби споживали джем із чорниці [28]. У клінічних випробуваннях було показано, що вживання антоціанів дійсно сприяє покращенню денного, сутінкового та нічного зору. Проте вплив антоціанів на зорові фрункції спостерігали не в усіх експериментах, а це залежало від дози, її складу і тривалості [9].

Одним із механізмів, що пояснюють позитивну дію антоціанів на зір, є їх здатність відновлювати зоровий пігмент родопсин. При цьому встановлено, що глікозид та рутинозид ціанідину прискорювали регенерацію родопсину, а похідні дельфрінідину не мали жодного впливу. Під час дослідження in vitro було з'ясовано, що антоціани також здатні пригнічувати фротоокиснення бісретинолу А2Е - хромофрора ліпофрусцинових гранул, що накопичується 3 віком в епітеліальних клітинах сітківки та може призводити до порушення цілісності їх мембран. Оскільки загибель світлочутливих клітин сітківки ока сприймається як основна причина розвитку вікової макулодистрофрії, отримані результати дозволяють припустити, що антоціани можуть бути ефективним профрілактичним засобом цього дегенеративного захворювання [29, 30].

Крім того, антоціани мають розслаблювальну дію на циліарний м'яз, що важливо для лікування короткозорості та глаукоми. Варто зазначити, що вживання антоціанів покращує транзиторний міопічний зсув, темну адаптацію та кровообіг сітківки у пацієнтів 3 глаукомою нормального напруження [30].

\section{Протизапальна дія антоціанів}

Запалення захищає організм від подразників. Зазвичай це вважають корисним для організму, але тривале хронічне запалення може бути шкідливим і призвести до розвитку різних захворювань, таких, як ожиріння, діабет 2 типу, серцево-судинні захворювання та багато видів раку.

При гострому запаленні макрофраги виробляють АФК, видаляючи сторонні частинки та індукуючи запальні цитокіни. Рівні АФК у клітині збалансовані за допомогою антиоксидантних ензимів, що детоксикують. Проте, коли гостре запалення переходить у хронічне, утворення АФК збільшується і виходить 3-під контролю, що сприятиме активації факторів запалення, посилить запальну відповідь і мутації генів і, врешті-решт, призведе до раку. Багато досліджень показало, що антоціани мають сильну протизапальну активність як in vivo, так i in vitro, їх ефрективним механізмом може бути здатність очищати АФК, знижувати рівень прозапальних цитокінів та регулювати активність антиоксидантів, зокрема супероксиддисмутази [10, 31].

Антоціани для профрілактики серцево-су-

\section{динних захворювань}

Результати проведених досліджень свідчать про те, що антоціани допомагають запобігти порушенням в організмі, які призводять до серцево-судинних захворювань - групи хвороб серця та кровоносних судин, що є основною причиною смертності в усьому світі. Зокрема, показано, що регулярне вживання антоціанів у їжу знижує концентрацію в плазмі ліпопротеїнів низької щільності, агрегацію тромбоцитів, імовірність розвитку артеріальної гіпертензії та ендотеліальної дисфункції. Завдяки інгібуванню ангіотензинперетворювального ензиму, що активує гормон ангіотензин, відповідальний за звуження судин, антоціани сприяють зниженню артеріального тиску. Крім цього, антоціани підвищують активність ендотеліальної синтази оксиду азоту і збільшують, таким чином, вивільнення оксиду азоту, що володіє вазодилатуючими, протитромбозними, антиатерогенними й антипролісреративними властивостями.

Сприятливий вплив антоціанів на серцево-судинну систему зумовлений також їх протизапальними й антиагрегатними властивостями. Як протизапальні агенти антоціани можуть пригнічувати експресію генів цитокінів, що кодують медіатори запалення, серед яких ключове місце займає сигнальний шлях ядерного фрактора NF-kappa-B (NF-kB). Антоціани також здатні інгібувати експресію гена, що кодує циклооксигеназу-2, яка бере участь у синтезі простагландинів, що мають протизапальну активність.

Вживання антоціанів - ефективна профрілактика атеросклерозу, зумовленого звуженням судин та зниженням кровотоку за рахунок відкладення холестеролу та деяких фрракцій ліпо- 
протеїнів у просвіті судин. Вони проявляють свої антиатерогенні властивості завдяки супресуючому впливу на утворення тромбоцитарних протеїнів хемокінів, що беруть участь у залученні циркулюючих лейкоцитів та клітин-попередників до місця ушкодження ендотелію.

Наведені приклади являють собою лише малу частину даних про сприятливий вплив антоціанів на стан серцево-судинної системи. На сьогодні цю групу сполук розглядають як есрективні профрілактичні засоби проти серцево-судинних патологій [1, 9, 10, 32].

\section{Антиканцерогенні ефекти}

Протиракові властивості антоціанів тісно пов'язані з їх антиоксидантною здатністю та індукцією цитотоксичної дії проти ракових клітин [33].

Чисті антоціани та багаті на антоціани екстракти пригнічують проліферацію клітин, блокуючи різні стадії клітинного циклу та їх регуляторні протеїни. Цікаво, що вони можуть вибірково пригнічувати проліфрерацію ракових клітин, але мало впливають на проліферацію нормальних клітин. Крім того, антоціани пригнічують ангіогенез, тим самим пригнічуючи ріст і метастазування пухлин [10, 34].

Антиканцерогенні властивості антоціанів зумовлені їх здатністю переривати клітинний цикл, індукувати апоптоз, блокувати утворення нових судин (антиангіогенні властивості), інгібувати окиснювальне ушкодження ДНК, активувати детоксикацію ензимів, а також здатність інгібувати циклооксигеназу і модулювати імунну мікровідповідь у тому числі [23].

Про антиангіогенну дію антоціанів повідомлялося в кількох роботах. Багаті на антоціани екстракти чорниці, журавлини, бузини та полуниці значно пригнічують експресію пероксиду водню та індукованого фрактором росту пухлини фрактора росту ендотелію судин у клітинах-кератиноцитах людини [1].

Таким чином, антоціани мають потенціал хіміопрофрілактики.

Антоціани для профрілактики метаболічних порушень

Як фрункціональні компоненти харчування антоціани можуть бути використані для запобігання ожирінню, лікування неалкогольної жирової хвороби печінки та діабету 2 типу. Дослідження на людях та експериментальних тваринах дозволили пояснити молекулярні механізми, за допомогою яких вони регулюють жировий і вуглеводний обмін та знижують резистентність до інсуліну [9, 15, 28, 35].

Антоціани також здатні знизити резистентність до інсуліну, підвищуючи експресію регульованого інсуліном гена протеїна-транспортера глюкози - Глют 4 шляхом активації і фрос- фрорилювання $\alpha$-субодиниці АМФ-активованої протеїнкінази в білій жировій тканині, водночас інгібуючи вироблення надлишку глюкози в печінці [35]

Антоціани чинять захисну дію на $\beta$-клітини підшлункової залози, зменшуючи мітохондріальне продукування активних фрорм кисню. Вони можуть модулювати антиоксидантний захист, активуючи антиокиснювальні ензими та сприяючи синтезу відновленого глутатіону в печінці. Так, приймання антоціанів відновлює рівень глутатіонпероксидази 3, який значно знижується при споживанні їжі з високим вмістом жиру [35].

При надмірному накопиченні жирової тканини порушуються процеси кровопостачання жирових клітин адипоцитів, з'являються вогнища некрозу і спостерігають інфрільтрацію жирової тканини макрофрагами, що призводить до надмірного утворення прозапальних цитокінів та підвищення рівня циркулюючих вільних жирних кислот, що спричиняють системне запалення. Антоціани покращують метаболізм жирних кислот і тригліцеридів за рахунок підвищення активності ліпопротеїнліпази у скелетних м'язах. Вони також пригнічують приріст маси тіла, відновлюють порушену фрункцію печінки і значно збільшують концентрацію гормону адипонектину, який виробляють жирові клітини, шляхом активації АМФ-активованої протеїнкінази, водночас знижуючи рівні інсуліну та лептину. Інший механізм зменшення гіперглікемії та покращення чутливості до інсуліну пов'язаний із пригніченням антоціанами експресії ретинолозв'язувального протеїну-4 [9].

Дія антоціанів на неалкогольну жирову хворобу печінки і діабетичну нефропатію також включає зниження накопичення ліпідів та поліпшення ліпідного профрілю в печінці, послаблення інсулінорезистентності, підвищення рівня рецептора, що активується проліфератором пероксисоми $\alpha$, зменшення запалення та окиснювального стресу $[9,15,23,28,35]$.

Здатність антоціанів індукувати секрецію інсуліну перебуває в порядку збільшення: пеларгонідин-3-галактозид - ціанідин-3-глюкозид дельфрінідин-3-глюкозид. Цей висновок демонструє, що кількість гідроксильних груп на В-кільці антоціанів відіграє вирішальну роль в їх здатності секретувати інсулін. Проте ціанідин, дельфрінідин, пеларгонідин, мальвідин і петунідин не потенціюють значної секреції інсуліну [1].

Вплив на нейродегенеративні захворювання

Нейродегенеративні захворювання характеризуються втратою певних популяцій нейронів у головному мозку, стовбурі мозку і спинному 
мозку, що призводить до значних когнітивних та/або моторних розладів.

Апоптоз лежить в основі патогенезу багатьох захворювань людини, включаючи нейродегенеративні розлади, такі, як хвороба Альцгеймера і хвороба Паркінсона. У цих випадках збільшується швидкість апоптозу, що спричиняє ушкодження тканин.

Дієта, багата на антоціани, пов'язана зі зниженням ризику розвитку нейродегенеративних захворювань через пряме знешкодження АФК, підвищення активності антиоксидантних ензимів (супероксиддисмутази і каталази), збільшення зниженого рівня глутатіону та зменшення вмісту малонового діальдегіду [31, 36].

Було показано позитивні результати лікування хвороби Альцгеймера екстрактами, багатими на антоціани. Ці екстракти можуть знижувати рівень $\beta$-амілоїдного пептиду і перетворювати його агрегацію в альтернативну, нетоксичну фрорму [37].

Крім того, вживання антоціанів людьми похилого віку з ризиком розвитку деменції покращує процеси пам'яті за рахунок посилення нейронної сигналізації у мозкових центрах, що опосередковують цю фрункцію.

3 огляду на те, що антоціани є потужними антиоксидантами, вони можуть ефективно запобігати ушкодженню вільними радикалами клітин головного мозку, що виробляють дофамін, таким чином пригнічуючи розвиток хвороби Паркінсона [10, 31, 37].

\section{Антибактеріальні ефекти}

Поліфенольні сполуки, включаючи антоціани, мають антимікробну активність щодо широкого спектра мікроорганізмів, особливо пригнічуючи ріст харчових патогенів. Антоціани проявляють антимікробну активність за допомогою кількох механізмів, наприклад, індукованого ушкодження клітин шляхом руйнування клітинної стінки, мембрани та міжклітинного матриксу [1].

Дослідження антибактеріальних властивостей показало, що багаті на антоціани екстракти пригнічують ріст широкого спектра патогенних бактерій людини, як грамнегативних, так і грампозитивних [10]. Хоча інгібування є значно більш очевидним у грамнегативних бактерій, порівняно з грампозитивними, через їх структурні варіації.

J. Cote та ін. [38] повідомляють, що екстракт журавлини мав антибактеріальну активність щодо Enterococcus faecium, стійкого до ванкоміцину, синьогнійної і кишкової паличок, золотистого стафрілокока.

Антоціани також мають противірусні властивості. Останні дослідження in vitro показали, що вони можуть пригнічувати реплікацію вірусів, таких, як простий герпес, вірус парагрипу, синцитіальний вірус, ВІЛ, ротавірус та аденовірус [38].

Потенційні переваги антоціанів для здоров'я підсумовано в таблиці. Вони включають антиоксидантну, протипухлинну, протидіабетичну, нейропротекторну дію, дію проти ожиріння, антиангіогенез, профрілактику серцево-судинних захворювань [40].

Таблиця - Вплив антоціанів на організм людини

\begin{tabular}{|c|c|c|c|c|c|}
\hline \multicolumn{6}{|c|}{ Дія антоціанів } \\
\hline $\begin{array}{c}\text { нейро- } \\
\text { протекторна }\end{array}$ & $\begin{array}{c}\text { кардіо- } \\
\text { протекторна }\end{array}$ & $\begin{array}{c}\text { антиокси- } \\
\text { дантна }\end{array}$ & $\begin{array}{c}\text { проти- } \\
\text { діабетична }\end{array}$ & проти ожиріння & протипухлинна \\
\hline$\downarrow$ Ішемія & $\downarrow$ Глутатіон & $\begin{array}{l}\downarrow \text { Мітохонд- } \\
\text { ріальне } \\
\text { ушкодження }\end{array}$ & $\begin{array}{l}\downarrow \text { Синтез } \\
\text { глюкози }\end{array}$ & $\downarrow$ Ліпіди плазми & $\uparrow$ Апоптоз \\
\hline $\begin{array}{l}\downarrow \text { Агрегація } \\
\text { протеїну }\end{array}$ & $\begin{array}{c}\downarrow \text { Активні } \\
\text { фрорми кисню }\end{array}$ & $\begin{array}{c}\downarrow \text { Активні } \\
\text { форми кисню }\end{array}$ & $\begin{array}{c}\downarrow \text { Абсорбція } \\
\text { глюкози }\end{array}$ & $\downarrow$ Жирні кислоти & $\begin{array}{c}\uparrow \text { Автофрагія } \\
\text { в онкотичних } \\
\text { клітинах }\end{array}$ \\
\hline$\downarrow$ Апоптоз & $\begin{array}{c}\downarrow \text { Активність } \\
\text { лізосомальних } \\
\text { ензимів }\end{array}$ & $\downarrow$ Оксид азоту & $\begin{array}{c}\downarrow \text { Вивільнення } \\
\text { глюкози } 3 \\
\text { печінки }\end{array}$ & $\downarrow$ Тригліцериди & $\begin{array}{c}\uparrow \text { Модуляція } \\
\text { сигнальної } \\
\text { трансдукції } \\
\text { шляху }\end{array}$ \\
\hline $\begin{array}{c}\downarrow \text { Глутаматна } \\
\text { ексайто- } \\
\text { токсичність }\end{array}$ & $\begin{array}{c}\uparrow \text { Активність } \\
\text { ензимів міто- } \\
\text { хондріального } \\
\text { та дихального } \\
\text { ланцюгів }\end{array}$ & $\begin{array}{c}\downarrow \text { Пероксидне } \\
\text { окиснення } \\
\text { ліпідів }\end{array}$ & $\begin{array}{c}\downarrow \text { Інсуліно- } \\
\text { подібний } \\
\text { фрактор росту-1 }\end{array}$ & $\begin{array}{c}\downarrow \text { Ліпопротеїни } \\
\text { дуже низької } \\
\text { щільності }\end{array}$ & $\downarrow$ Ангіогенез \\
\hline$\downarrow \mathrm{Ca}^{2+}$ & $\begin{array}{c}\downarrow \text { Ушкодження } \\
\text { міокарда }\end{array}$ & - & $\begin{array}{c}\downarrow \text { Інсуліно- } \\
\text { резистентність }\end{array}$ & $\begin{array}{c}\uparrow \text { Ліпопротеїни } \\
\text { високої щільності }\end{array}$ & $\begin{array}{c}\downarrow \text { Метастатична } \\
\text { міграція }\end{array}$ \\
\hline $\begin{array}{c}\downarrow \text { Нейро- } \\
\text { запалення }\end{array}$ & - & - & $\begin{array}{c}\uparrow \text { Панкреа- } \\
\text { тичний інсулін }\end{array}$ & $\begin{array}{l}\downarrow \beta \text {-окиснення } \\
\text { жирних кислот }\end{array}$ & $\uparrow$ Антиоксидант \\
\hline $\begin{array}{c}\downarrow \text { Активні } \\
\text { фрорми кисню }\end{array}$ & - & - & - & $\downarrow$ Ризик ожиріння & - \\
\hline
\end{tabular}


ВИСНОВКИ. За останні десятиліття інтерес до харчових фенольних сполук, включаючи антоціани, значно зріс. Антоціани - це фрітопігменти, що містяться в кількох рослинах. Вони добре відомі своєю антиоксидантною активністю, що можна пояснити їх унікальною структурою. Таким чином, дослідження, підсумовані в цьому огляді, демонструють важливість даних сполук як при- родних барвників, маркерів стресу для рослин і профрілактики багатьох хронічних захворювань у людини. Антоціани можна використовувати для запобігання ряду захворювань, включаючи серцево-судинні захворювання, рак, діабет, деякі метаболічні захворювання та мікробні іноекції. Ці сполуки також покращують зір і мають нейропротекторну дію.

\section{СПИСОК ЛІТЕРАТУРИ}

1. Anthocyanins: A comprehensive review of their chemical properties and health effects on cardiovascular and neurodegenerative diseases / R. Mattioli, A. Francioso, L. Mosca, P. Silva // Molecules. - 2020. No. 25 (17). - P. 3809. DOI: 10.3390/molecules25173809

2. Chemical studies of anthocyanins: A review / A. Castañeda-Ovando, M. de Lourdes PachecoHernández, M. E. Páez-Hernández [et al.] // Food Chem. - 2009. - 113. - P. 859-871. DOI: 10.1016/j. foodchem.2008.09.001.

3. Ahmed N. U. Anthocyanin biosynthesis for cold and freezing stress tolerance and desirable color in Brassica rapa / N. U. Ahmed // Funct. Integr. Genomics. 2015. - No. 15 (4). - P. 383-394. DOI: 10.1007/s10142014-0427-7.

4. Tomato Hoffman's anthocyaninless gene encodes a bHLH transcription factor involved in anthocyanin biosynthesis that is developmentally regulated and induced by low temperatures / Z. Qiu, X. Wang, J. Gao [et al.] // PloS One. - 2016. - No. 11 (3). - P. e0151067. DOI: 10.1371/journal.pone.0151067.

5. Anthocyanidins and anthocyanins: Colored pigments as food, pharmaceutical ingredients, and the potential health benefits / H. E. Khoo, A. Azlan, S. T. Tang, S. M. Lim // Food Nutr. Res. - 2017. - No. 61. P. 1361779. DOI: 10.1080/16546628.2017.1361779.

6. He J. Anthocyanins: Natural colorants with healthpromoting properties /J. He, M. M. Giusti // Annu. Rev. Food Sci. Technol. - 2010. - No. 1. - P. 163-187. DOI: 10.1146/annurev.food.080708.100754.

7. Hock Eng Khoo. Evidence-based therapeutic effects of anthocyanins from foods / Hock Eng Khoo, See Meng Lim, Azrina Azlan // Pakistan Journal of Nutrition. 2019. - 18. - P. 1-11. DOI: 10.3923/pjn.2019.1.11

8. Tena N. State of the art of anthocyanins: Antioxidant activity, sources, bioavailability, and therapeutic effect in human health / N. Tena, J. Martín, A. G. Asuero // Antioxidants (Basel, Switzerland). - 2020. - No. 9 (5). P. 451. DOI: 10.3390/antiox9050451

9. Антоцианы как компоненты фрункционального питания / Р. С. Юдина, Е.И.Гордеева, О. Ю. Шоева [и др.] // Вавиловский журн. генетики и селекции. 2021. - 25, № 2. - C. 178-189.

10. Rana Nassour. Anthocyanin pigments: Structure and biological importance / Nassour Rana, Ayash Abdulkarim, Al-Tameemi Kanaan // Journal of Chemical and Pharmaceutical Sciences. - 2020. - No. 13 (4). P. 45-57.
11. Health benefits of anthocyanins and molecular mechanisms: Update from recent decade / Daotong Li, Pengpu Wang, Yinghua Luo [et al.] // Chen. Critical Reviews in Food Science and Nutrition. - 2017. No. 57 (8). - P. 1729-1741, DOI: 10.1080/10408398. 2015.1030064.

12. A review of factors affecting anthocyanin bioavailability: Possible implications for the inter-individual variability / M. E. Eker, K. Aaby, I. Budic-Leto [et al.] // Foods. - 2020. - No. 9 (1). - P. 2. DOI: 10.3390/ foods 9010002 .

13. Deroles S. Anthocyanin biosynthesis in plant cell cultures: A potential source of natural colourants, inanthocyanins: Biosynthesis, functions, and applications / K. Gould, K. Davies, C. Winefield. - 2009. - Springer. P. 107-167.

14. Bioavailability of Anthocyanins / A. Faria, I. Fernandes, N. Mateus, C. Calhau // Natural Products. Phytochemistry, Botany and Metabolism of Alkaloids, Phenolics and Terpenes / In: K. Ramawat, J.M. Mérillon. (editors). - Springer, Berlin, Heidelberg. - 2013. DOI: 10.1007/978-3-642-22144-6_75.

15. Azzini E. Antiobesity effects of anthocyanins in preclinical and clinical studies / E. Azzini, J. Giacometti, G. L. Russo // Oxidative Medicine and Cellular Longevity. 2017. - P. 2740364. DOI: 10.1155/2017/2740364.

16. Anthocyanins in nutrition: Biochemistry and health benefits: From translational research to a humanistic approach - Volume III // María Ines De Rosas, Leonor Deis, Liliana Martinez [etal.]//Psychiatry and Neuroscience Update; P. Á. Gargiulo, H. L. Mesones Arroyo (eds.). Springer Nature. - Switzerland AG. - 2019. DOI: 10.1007/ 978-3-319-95360-1_12.

17. Fang J. Some anthocyanins could be efficiently absorbed across the gastrointestinal mucosa: extensive presystemic metabolism reduces apparent bioavailability / J. Fang // Journal of Agricultural and Food Chemistry. 2014. - 62 - P. 3904-3911.

18. Absorption and metabolites of anthocyanins and phenolic acids after consumption of purple wheat crackers and bars by healthy adults / T. H Gamel, A. J. Wright, A. J. Tucker [et al] // J. Cereal Sci. - 2019. - 86. - P. 6068. DOI: 10.1016/j.jcs.2018.11.017.

19. Benefits of polyphenols on gut microbiota and implications in human health / F. Cardona, C. AndrésLacueva, S. Tulipani [et al.] // The Journal of Nutritional Biochemistry. - 2013. - 24 (8). - P. 1415-1422. DOI: 10.1016/j.jnutbio.2013.05.001. 
20. Metabolism and prebiotics activity of anthocyanins from black rice (Oryza sativa L.) in vitro / Y. Zhu, H. Sun, S. He [et al.] // PloS One. - 2018. - 13 (4). P. e0195754. DOI: 10.1371/journal.pone.0195754.

21. Lavefve L. Berry polyphenols metabolism and impact on human gut microbiota and health / L. Lavefve, L. R. Howard, F. Carbonero // Food \& Function. - 2020. 11 (1). - P. 45-65. DOI: 10.1039/c9fo01634a.

22. Mixture of blackberry leaf and fruit extracts alleviates non-alcoholic steatosis, enhances intestinal integrity, and increases Lactobacillus and Akkermansia in rats / S. Park, Cho S. M, Jin B. R [et al.] // Experimental Biology and Medicine (Maywood, N. J.). - 2019. 244 (18). - P.1629-1641.DOI:10.1177/1535370219889319.

23. Chemistry, pharmacology and health benefits of anthocyanins / A. Smeriglio, D. Barreca, T. Bellocco, D. Trombetta // Phytotherapy Research. - 2016. 30 (8). - P. 1265-1286. DOI: 10.1155/2017/2740364.

24. Enaru B. Anthocyanins: Factors affecting their stability and degradation / B. Enaru, G. Dretcanu, T. D. Pop [et al.] // Antioxidants. - 2021. - 10. - P. 1967. DOI: 10.3390/antiox10121967.

25. Ali H. M. Antiradical and reductant activities of anthocyanidins and anthocyanins, structure-activity relationship and synthesis / H. M. Ali, W. Almagribi, M. N. AlRashidi // Food Chemistry. - 2016. - 194. - P. 1275-1282. DOI: 10.1016/j.foodchem.2015.09.003.

26. Kähkönen M. P. Antioxidant activity of anthocyanins and their aglycons / M. P. Kähkönen, M. Heinonen // Journal of Agricultural and Food Chemistry. - 2003. 51 (3). - P. 628-633. DOI: 10.1021/jf025551i.

27. Miguel M. G. Anthocyanins: Antioxidant and/or anti-inflammatory activities / M. G. Miguel // J. Appl. Pharm. Sci. -2011. -1. - P. 7-15. -Access mode : http:// japsonline.com/admin/php/uploads/117 pdf.pdf

28. Ghosh D. Anthocyanins and anthocyanin-rich extracts: role in diabetes and eye function / D. Ghosh, T. Konishi // Asia Pacific Journal of Clinical Nutrition. 2007. - 16 (2). -P. 200-208.

29. Nutrients for prevention of macular degeneration and eye-related diseases / H. E. Khoo, H. S. Ng, W. S. Yap [et al.] // Antioxidants (Basel, Switzerland). 2019. - 8 (4). - P. 85. DOI: 10.3390/antiox8040085

30. Nomi Y. Therapeutic effects of anthocyanins for vision and eye health / Y. Nomi, K. Iwasaki-Kurashige, H. Matsumoto // Molecules (Basel, Switzerland). - 2019. 24 (18). - P. 3311. DOI: 10.3390/molecules24183311.

31. Grzegorz Bartosz. Fluorescent products of anthocyanidin and anthocyanin oxidation / G. Bartosz,
M. Grzesik-Pietrasiewicz, I. Sadowska-Bartosz // Journal of Agricultural and Food Chemistry. - 2020. - 68 (43).12019-12027. DOI: 10.1021/acs.jafc.0c04755.

32. Wallace T. C. Systematic review of anthocyanins and markers of cardiovascular disease // T. C. Wallace, M. Slavin, C. L. Frankenfeld // Nutrients. -2016. - 8 (1). P. 32. DOI: $10.3390 /$ nu8010032.

33. Anticancer effects of Bilberry anthocyanins compared with NutraNanoSphere encapsulated Bilberry anthocyanins // S. P. Thibado, J. T. Thornthwaite, T. K. Ballard, B. T. Goodman // Molecular and Clinical Oncology. - 2018. - 8 (2). - P. 330-335. DOI: 10.3892/ mco.2017.1520.

34. Tsakiroglou P. Role of berry anthocyanins and phenolic acids on cell migration and angiogenesis: An updated overview / P. Tsakiroglou, N. E. VandenAkker, C. Del Bo' [et al.] // Nutrients. - 2019. - 11 (5). - P. 1075. DOI: $10.3390 /$ nu11051075.

35. Tsuda T. Recent progress in anti-obesity and anti-diabetes effect of berries / T. Tsuda // Antioxidants (Basel, Switzerland). - 2016. - 5 (2). - P. 13. DOI: 10. 3390/antiox5020013.

36. Winter A. N. Anthocyanins and their metabolites as therapeutic agents for neurodegenerative disease // A. N. Winter, P. C. Bickford // Antioxidants (Basel, Switzerland). - 2019. - 8 (9). - P. 333. DOI: 10.3390/ antiox8090333.

37. Neuroprotective effects of anthocyanin- and proanthocyanidin-rich extracts in cellular models of Parkinson's disease / K. E. Strathearn, G. G.Yousef, M. H. Grace [et al.] // Brain Research. - 2014. - 1555. P. 60-77. DOI: 10.1016/j.brainres.2014.01.047.

38. Antimicrobial effect of cranberry juice and extracts / J. Cote, S. Caillet, G. Doyon [et al.] // Food Control. - 2011. - 22. - P. 1413-1418. DOI: 10.1016/j. foodcont.2011.02.024.

39. The signaling pathways, and therapeutic targets of antiviral agents: focusing on the antiviral approaches and clinical perspectives of anthocyanins in the management of viral diseases / P. M. Pour, S. Fakhri, S. Asgary [et al.] // Front. Pharmacol. - 2019. - 10. - P. 1207. DOI: 10.3389/fphar.2019.01207.

40. Salehi B. The therapeutic potential of anthocyanins: Current approaches based on their molecular mechanism of action / B. Salehi, J Sharifi-Rad, F. Cappellini [et al.] // Frontiers in Pharmacology. - 2020. - 11. P. 1300. DOI: 10.3389/fphar.2020.01300.

\section{REFERENCES}

1. Mattioli, R., Francioso, A., Mosca, L., \& Silva P. (2020). Anthocyanins: A Comprehensive review of their chemical properties and health effects on cardiovascular and neurodegenerative diseases. Molecules, 25 (17), 3809. DOI: 10.3390/molecules 25173809

2. Castañeda-Ovando, A., de Lourdes PachecoHernández, M., Páez-Hernández, M.E., Rodríguez, J.A., \& Galán-Vidal, C.A. (2009). Chemical studies of anthocyanins: Areview. Food Chem., 113, 859-871. DOI: 10.1016/j.foodchem.2008.09.001.
3. Ahmed, N.U., Park, J.-I., Jung, H.-J., Hur, Y., \& Nou, I.-S. (2015). Anthocyanin biosynthesis for cold and freezing stress tolerance and desirable color in Brassica rapa. Funct. Integr. Genomics, 15 (4), 383-394. DOI: 10.1007/s10142-014-0427-7.

4. Qiu, Z., Wang, X., Gao, J., Guo, Y., Huang, Z., \& Du, Y. (2016). The tomato Hoffman's Anthocyaninless gene encodes a bHLH transcription factor involved in anthocyanin biosynthesis that is developmentally regulated and induced by low temperatures. PloS One, 11 (3), e0151067. DOI: 10.1371/journal.pone.0151067. 
5. Hock Eng Khoo, Azrina Azlan, Sou Teng Tang \& See Meng Lim (2017). Anthocyanidins and anthocyanins: colored pigments as food, pharmaceutical ingredients, and the potential health benefits. Food \& Nutrition Research, 61 (1), 1361779. DOI: 10.1080/16546628. 2017.1361779.

6. He, J. \& Giusti, M.M. (2010). Anthocyanins: Natura colorants with health-promoting properties. Annu. Rev. Food Sci. Technol., 1, 163-187. DOI: 10.1146/annurev. food.080708.100754.

7. Hock Eng Khoo, See Meng Lim and Azrina Azlan. (2019). Evidence-based therapeutic effects of anthocyanins from foods. Pakistan Journal of Nutrition, 18, 1-11. DOI: 10.3923/pjn.2019.1.11

8. Tena, N., Martín, J., \& Asuero, A.G. (2020). State of the art of anthocyanins: antioxidant activity, sources, bioavailability, and therapeutic effect in human health. Antioxidants (Basel, Switzerland), 9 (5), 451. DOI: 10.3390/antiox9050451

9. Yudina, R.S., Gordeeva, E.I., Shoeva, O.Y., Tikhonova, M.A., \& Khlestkina, E.K. (2021). Anthocyanins as functional food components. Vavilovskii zhurnal genetiki i selektsii, 25 (2), 178-189. DOI: 10.18699/ VJ21.022 [in Russian].

10. Rana Nassour, Abdulkarim Ayash, \& Kanaan Al-Tameemi. (2020). Anthocyanin pigments: Structure and biological importance Journal of Chemical and Pharmaceutical Sciences, 13 (4), 45-57.

11. Daotong Li, Pengpu Wang, Yinghua Luo, Mengyao Zhao \& Fang Chen (2017) Health benefits of anthocyanins and molecular mechanisms: Update from recent decade. Critical Reviews in Food Science and Nutrition, 57 (8), 1729-1741, DOI: 10.1080/10408398. 2015.1030064.

12. Eker M.E., Aaby K., Budic-Leto I., Rimac Brnčic S., El S.N., Karakaya S., Simsek S., Manach C. Wiczkowski W., \& de Pascual-Teresa S. (2020). A review of factors affecting anthocyanin bioavailability: Possible implications for the inter-individual variability. Foods., 9 (1), 2. DOI: $10.3390 /$ foods9010002.

13. Deroles, S. (2009). Anthocyanin biosynthesis in plant cell cultures: A potential source of natural colourants. In Anthocyanins: Biosynthesis, Functions, and Applications, Gould K, Davies K, Winefield C, Springer.

14. Faria, A., Fernandes, I., Mateus, N., \& Calhau, C. (2013). Bioavailability of Anthocyanins. In: Ramawat K. Mérillon JM. (eds) Natural Products. Phytochemistry, Botany and Metabolism of Alkaloids, Phenolics and Terpenes. Springer, Berlin, Heidelberg. DOI: 10.1007/9783-642-22144-6_75.

15. Azzini, E., Giacometti, J., \& Russo, G.L. (2017). Antiobesity effects of anthocyanins in preclinical and clinical studies. Oxidative Medicine and Cellular Longevity, 2017, 2740364. DOI: 10.1155/2017/2740364.

16. Rosas, María \& Deis, Leonor \& Martinez, Liliana \& Duran, Martin \& Malovini, Emiliano \& Bruño, Juan. (2019). Anthocyanins in nutrition: Biochemistry and health benefits: From translational research to a humanistic approach - Volume III. Gargiulo, P.Á., Mesones Arroyo, H.L. (Eds.). Psychiatry and Neuroscience Update; Springer Nature. - Switzerland AG. DOI: 10.1007/9783-319-95360-1_12.

17. Fang, J. (2014). Some anthocyanins could be efficiently absorbed across the gastrointestinal mucosa: extensive presystemic metabolism reduces apparent bioavailability. Journal of Agricultural and Food Chemistry, 62, 3904-3911.

18. Gamel, T.H., Wright, A.J., Tucker, A.J., Pickard, M., Rabalski, I., Podgorski, M., Di llio, N., O'Brien, C., \& Abdel-Aal, E.M. (2019). Absorption and metabolites of anthocyanins and phenolic acids after consumption of purple wheat crackers and bars by healthy adults. J. Cereal Sci., 86, 60-68. DOI: 10.1016/j.jcs.2018.11.017.

19. Cardona, F., Andrés-Lacueva, C., Tulipani, S., Tinahones, F.J., \& Queipo-Ortuño, M. I. (2013). Benefits of polyphenols on gut microbiota and implications in human health. The Journal of Nutritional Biochemistry, 24 (8), 1415-1422. DOI: 10.1016/j.jnutbio.2013.05.001.

20. Zhu, Y., Sun, H., He, S., Lou, Q., Yu, M., Tang, M., \& Tu, L. (2018). Metabolism and prebiotics activity of anthocyanins from black rice (Oryza sativa L.) in vitro. PloS One, 13 (4), e0195754. DOI: 10.1371/journal. pone.0195754.

21. Lavefve, L., Howard, L.R., , \& Carbonero, F., (2020). Berry polyphenols metabolism and impact on human gut microbiota and health. Food \& Function, 11 (1), 45-65. DOI: 10.1039/c9fo01634a.

22. Park, S., Cho, S.M., Jin, B.R., Yang, H.J., \& Yi, Q.J. (2019). Mixture of blackberry leaf and fruit extracts alleviates non-alcoholic steatosis, enhances intestinal integrity, and increases Lactobacillus and Akkermansia in rats. Experimental biology and medicine (Maywood, N.J.), 244 (18), 1629-1641. DOI: 10.1177I 1535370219889319.

23. Smeriglio, A., Barreca, D., Bellocco, E., \& Trombetta, D. (2016). Chemistry, pharmacology and health benefits of anthocyanins. Phytotherapy Research, 30 (8), 1265-1286. DOI: 10.1155/2017/2740364.

24. Khoo, H.E., Lim, S.M., \& Azlan, A. (2019). Evidence-based therapeutic effects of anthocyanins from foods. Pak. J. Nutr., 18, 1-11. DOI: 10.3923/pjn.2019.1.11

25. Ali, H.M., Almagribi, W., \&Al-Rashidi, M.N. (2016). Antiradical and reductant activities of anthocyanidins and anthocyanins, structure-activity relationship and synthesis. Food Chemistry, 194, 1275-1282. DOI: 10.1016/j. foodchem.2015.09.003.

26. Kähkönen, M.P., \& Heinonen, M. (2003). Antioxidant activity of anthocyanins and their aglycons. Journal of Agricultural and Food Chemistry, 51 (3), 628-633. DOI: $10.1021 / \mathrm{jf0} 25551 \mathrm{i}$.

27. Miguel, M.G. (2011). Anthocyanins: Antioxidant and/or anti-inflammatory activities. J. Appl. Pharm. Sci., 1, 7-15. Retrieved from: http://japsonline.com/admin/php/ uploads/117_pdf.pdf

28. Ghosh, D., \& Konishi, T. (2007). Anthocyanins and anthocyanin-rich extracts: role in diabetes and eye function. Asia Pacific Journal of Clinical Nutrition, 16 (2), 200-208.

29. Khoo, H.E., Ng, H.S., Yap, W.S., Goh, H., \& Yim, H.S. (2019). Nutrients for Prevention of Macular Degeneration and Eye-Related Diseases. Antioxidants (Basel, Switzerland), 8 (4), 85. DOI: 10.3390/antiox 8040085.

30. Nomi, Y., Iwasaki-Kurashige, K., \& Matsumoto, H. (2019). Therapeutic effects of anthocyanins for vision and eye health. Molecules (Basel, Switzerland), 24 (18), 3311. DOI: 10.3390/molecules24183311.

31. Grzegorz Bartosz, Michalina Grzesik-Pietrasiewicz, \& Izabela Sadowska-Bartosz. (2020). Fluorescent products of anthocyanidin and anthocyanin oxida- 
tion. Journal of Agricultural and Food Chemistry, 68 (43), 12019-12027. DOI: 10.1021/acs.jafc.0c04755.

32. Wallace, T.C., Slavin, M., \& Frankenfeld, C.L. (2016). Systematic review of anthocyanins and markers of cardiovascular disease. Nutrients, 8 (1), 32. DOI: 10.3390/nu8010032

33. Thibado, S.P., Thornthwaite, J.T., Ballard, T.K., \& Goodman, B.T. (2018). Anticancer effects of Bilberry anthocyanins compared with NutraNanoSphere encapsulated Bilberry anthocyanins. Molecular and Clinical Oncology, 8 (2), 330-335. DOI: 10.3892/mco.2017.1520.

34. Tsakiroglou, P., VandenAkker, N.E., Del Bo', C., Riso, P., \& Klimis-Zacas, D. (2019). Role of berry anthocyanins and phenolic acids on cell migration and angiogenesis: An updated overview. Nutrients, 11 (5), 1075. DOI: $10.3390 /$ nu11051075.

35. Tsuda, T. (2016). Recent progress in anti-obesity and anti-diabetes effect of berries. Antioxidants (Basel, Switzerland), 5 (2), 13. DOI: 10.3390/antiox5020013.

36. Winter, A.N., \& Bickford, P.C. (2019). Anthocyanins and their metabolites as therapeutic agents for neurodegenerative disease. Antioxidants (Basel, Switzerland), 8 (9), 333. DOI: 10.3390/antiox8090333.
37. Strathearn, K.E., Yousef, G.G., Grace, M.H., Roy, S.L., Tambe, M.A., Ferruzzi, M.G., Wu, Q.L., et al. (2014). Neuroprotective effects of anthocyanin- and proanthocyanidin-rich extracts in cellular models of Parkinson's disease. Brain Research, 1555, 60-77. DOI: 10.1016/j.brainres.2014.01.047.

38. Cote, J., Caillet, S., Doyon, G., Dussault, D., Sylvain, J.F., \& Lacroix, M., Antimicrobial effect of cranberry juice and extracts. Food Control, 22, 2011, 1413-1418. DOI: 10.1016/j.foodcont.2011.02.024.

39. Pour, P.M., Fakhri, S., Asgary, S., Farzaei, M.H., \& Echeverria, J. (2019). The signaling pathways, and therapeutic targets of antiviral agents: focusing on the antiviral approaches and clinical perspectives of anthocyanins in the management of viral diseases. Front. Pharmacol., 10, 1207. DOI: 10.3389/fphar.2019.01207.

40. Salehi, B., Sharifi-Rad, J., Cappellini, F., Reiner, Ž., Zorzan, D., Imran, M., Sener, B., et al. (2020). The therapeutic potential of anthocyanins: Current approaches based on their molecular mechanism of action. Frontiers in Pharmacology, 11, 1300. DOI: 10.3389/ fphar.2020.01300.

\section{ANTHOCYANINS AND ANTHOCYANIDINS AS COMPONENTS OF FUNCTIONAL NUTRITION: BIOCHEMISTRY AND EFFECTS ON HUMAN HEALTH (LITERATURE REVIEW)}

\section{Summary}

Introduction. Anthocyanins and anthocyanidins are two types of red-blue plant flavonoids, mostly found in flowers and fruits of higher plants. The main difference between anthocyanin and anthocyanidin is that anthocyanin is a water-soluble vacuolar pigment whereas anthocyanidin is sugar-free counterpart of anthocyanin. They are based on the flavylium cation, an oxonium ion, with various groups substituted for its hydrogen atoms. Anthocyanins are formed by adding sugars to various side groups of the flavylium ion. The pigments are in glycosylated forms. Cyanidin, delphinidin, malvidin, peonidin, petunidin, and pelargonidin are six common anthocyanidins. Besides the use of anthocyanidins and anthocyanins as natural dyes, these colored pigments are potential pharmaceutical ingredients that give various beneficial health effects. Scientific studies, such as cell culture studies, animal models, and human clinical trials, show that anthocyanidins and anthocyanins have antioxidative and antimicrobial activities, improve visual and neurological health, and protect against various diseases.

This review summarizes the latest literature on the biological benefits of dietary anthocyanins, including antitumor activity, anti-inflammatory activity, neuroprotective activity, cardiovascular disease prevention, obesity, and antidiabetic activity, with a particular focus on molecular mechanisms of action. This review will help you better understand these dietary phytochemicals and use them for human health. This paper uses general scientific research methods, including expert-analytical review of scientific sources, analysis and synthesis of literature data.

The aim of the study - to summarize basic knowledge of biochemistry, regulation of anthocyanin biosynthesis in plants, molecular mechanisms of action, highlight some aspects of anthocyanin antioxidant activity and their bioavailability and discuss recent experimental data related to beneficial effects on human health.

Conclusions. The analysis of literature sources substantiates the relevance of the study of molecular mechanisms of action of anthocyanins, the importance of these compounds as natural dyes, stress markers for plants and prevention of many chronic human diseases and their use to prevent a number of diseases.

KEY WORDS: anthocyanins; anthocyanidins; pigments; bioavailability; antioxidants; antibacterial; antiinflammatory; antitumor; antidiabetic; anti-obese; neurodegenerative diseases; cardiovascular diseases; ophthalmology.

Адреса для листування: І. П. Кузьмак, Тернопільський національний медичний університет імені І. Я. Горбачевського моз України, майдан Волі, 1, Тернопіль, 46001, Україна, e-mail: kuzmak@tdmu.edu.ua. 